\title{
Influence of Effective Microorganisms on selected serum biochemical parameters in Japanese quails infected with Cryptosporidium parvum
}

\author{
RAJMUND SOKÓŁ, MICHAŁ GESEK*, MAŁGORZATA RAŚ-NORYŃSKA, \\ MARIA MICHALCZYK, SYLWIA KOZIATEK-SADKOWSKA
}

\begin{abstract}
Department of Parasitology and Invasive Diseases, *Department of Pathological Anatomy, Faculty of Veterinary Medicine, University of Warmia and Mazury in Olsztyn, Oczapowskiego 13, 10-719 Olsztyn, Poland
\end{abstract}

Sokół R., Gesek M., Raś-Noryńska M., Michałczyk M., Koziatek-Sadłowska S. Influence of Effective Microorganisms on selected serum biochemical parameters in Japanese quails infected with Cryptosporidium parvum

\section{Summary}

Dietary supplements and symbiotic cultures of bacteria are used in commercial poultry farms to stimulate the birds' metabolism. The aim of the study was to evaluate the influence of Effective Microorganisms (EMTM) administered in feed and water to quails infected and not infected with $C$. parvum on selected serum biochemical parameters. The resulting infection with $C$. parvum was subclinical, and parasitological tests revealed no ooysts in fecal samples, but in histopathological examination parasites were seen in the tissue samples. Blood for biochemical analysis was sampled on days $0,3,6$ and 9 post infection. Lower CHOL levels, lower LDH activity and higher TP content were observed in quails administered EM. Changes in the remaining parameters (ALT, AST, ALB) remained within the respective norms.

Keywords: Effective Microorganisms, biochemical parameters, Cryptosporidium parvum, quails

Probiotics, prebiotics, synbiotics, natural gut flora (NGF) and Effective Microorganisms $\left(\mathrm{EM}^{\mathrm{TM}}\right)$ are administered in commercial poultry farms to stimulate the birds' immunity $(1,22-24)$. The concept of effective microorganisms was developed by Professor Teruo Higa of Japan in 1982. EM consists of around 80 different microorganisms (lactic acid bacteria, yeasts, actinomycetes, photosynthetic bacteria and fermenting fungi) that assist one another for survival in the environment and thereby form the synergy that fights off pathogens $(28,29)$. It is widely used in agriculture and municipal sewage treatment plants to eliminate the odor produced by decomposing sewage sludge. EM rapidly proliferate in the target environment (soil, sewage, crops, farm buildings or living organisms) and inhibit the development of pathogenic microbes. In some countries, EM is widely used in bird breeding $(2,3,5,12)$. EM regulate the composition of gut flora, improve feed conversion, stimulate the growth and development of birds $(16,21$, $26,27)$. Beneficial microorganisms prevent intestinal infections and accelerate convalescence. They boost immunity by increasing antibody levels, stimulating the phagocytic activity of macrophages and increasing cytotoxic T cell counts $(8,20)$.
Several authors also studied blood parameters during probiotic, prebiotic, synbiotic and EM administration. Kalavathy et al. (11) studied the effect of 12 Lactobacillus strains on growth performance, serum lipids weight of the organs of broiler chickens from 1 to 42 day of age. Salim et al. (19) evaluated the hematological, biochemical (AST, ALT, cholesterol, triglycerides, total protein, albumin) and immunological effect of probiotics (Bacillus subtilis) on Hubbard broilers. The earlier study of Santoso et al. (22) included effects of Bacillus subtilis addition on the lipid fraction (triacylglycerol, total cholesterol and phospholipid) in the liver, serum and carcasses of broiler chicks. Shareef and Al-Dabbagh (23) assayed total protein, triglycerides, cholesterol, calcium uric acid, glucose, alanine aminotransferase (ALT), aspartate aminotransferase (AST) in broiler chickens during probiotic addition (Saccharomyces cerevisiae). The available literature also relates effects of EM addition on blood parameters. Wondmeneh et al. (31) analyzed effects of EM supplementation (in feed and water - separate and mixed) in broiler chickens and showed possitive effects to weight gain and total blood cholesterol.

Cryptosporidium spp. are widely spread coccidia of the phylum Apicomplexa, class Gregarinomorphea, 
subclass Cryptogregaria, which colonize the epithelial lining of gastrointestinal and respiratory systems in many species of mammals, birds and reptiles (18). Birds are colonized by Cryptosporidium baileyi, gali, meleagridis and parvum $(13,15,16,23)$. High stocking density and poor sanitation contribute to the spread of infections in animal and poultry farms. The protozoa penetrate the intestinal epithelium. They can impair sodium/glucose cotransport and glucose-dependent water flow causing disturbances in intestinal water retention. Cryptosporidium induce morphological changes such as atrophy of intestinal villi, crypt dilation and inflammatory cell infiltration. Most infections are symptom-free, but they can be manifested by diarrhea of differing severity (from weak to abundant and watery diarrhea that leads to dehydration). Many mammals, reptiles and birds are carriers of Cryptosporidium, and clinical symptoms of infection are increased by stress or immunosuppression $(13,15,16,22)$.

The biochemical profile of serum changes due to age, nutrition, heredity, infectious diseases, vaccination, supplement addition, parasitic infestation, thus investigations concerning analysis of the biochemical profile are needed.

The aim of this study was to determine the influence of EM administered with feed and water to Japanese quails (future egg-layers) infected and not infected with C. parvum on selected serum biochemical parameters.

\section{Material and methods}

Eighty two-day-old female Japanese quails (Coturnix coturnix japonica) were obtained from a commercial farm of 8,000 birds. The birds were transported to the aviary and placed in isolated cages at 20 individuals per cage. Fecal samples were collected twice and tested with the Crypto/Giardia Duo-Strip ${ }^{\circledR}$ kit (Coris BioConcept, Gembloux - Belgium) to exclude the presence of Cryptosporidium spp. oocysts. Adaptation to feed and water containing EM lasted 10 days. The EM dose administered to experimental birds was calculated on the basis of age requirements. Control group (C) birds were fed a standard diet throughout the experiment and had unlimited access to water. The EM group received a standard diet supplemented with EM and water supplemented with EM throughout the experiment. On day 10 both groups were divided into half and the selected birds were infected with the Cryptosporidium parvum oocysts, creating within the $\mathrm{C}$ and ER groups the experimental groups $\mathrm{Cr}$ and $\mathrm{EM} / \mathrm{Cr}$.

The following EM products were used in the study:

- fermented herbal extract (Multikraft, Pichl bei WelsAustria) - dietary supplement for all animal species, brown colored, with a sweet and sour aroma, $\mathrm{pH} 3.5$, with the following composition: $97 \%$ water, $0.3 \%$ crude protein, $0.1 \%$ fat, $1.3 \%$ crude ash, $0.6 \%$ crude fiber. The product contains sugarcane molasses, cumin, yarrow, anise, fennel, birch leaves, goldenrod, rosemary, peppermint, marshmallow root and raspberry leaves. The recommended dose for poultry is $31 / 10001$ water, three times a week. The water solution with the appropriate EM dose was administered immediately after preparation with drinking water ad libitum, twice daily, every $12 \mathrm{hr}$ (unconsumed water was removed);
- MultiPROFIT (Agro Concept, Puławy - Polska) - synbiotic preparation for animals containing wheat bran and EM, with identical composition to that of the other supplement. The product was thoroughly mixed with feed at the recommended dose of $5 \mathrm{~kg} / \mathrm{ton}$ per bird, and served ad libitum in feeders (unconsumed feed was removed daily).

Feed supplementation with EM: an amount of feed identical to the amount of the EM dose calculated for a given bird group (EM, EM/Cr) was sampled from the daily feed ration for 40 birds. Both amounts were mixed for 3 minutes, and feed was added in identical portions to the mixture until enough feed was prepared for one serving. The freshly prepared mixture was administered ad libitum twice daily.

Infection with C. parvum: each bird from groups $\mathrm{Cr}$ and $\mathrm{EM} / \mathrm{Cr}$ was administered $0.5 \mathrm{ml}$ of aqueous solution containing $10^{6}$ C. parvum oocysts suspended in $0.9 \%$ saline solution $(14,15)$ directly into the beak, on days 10 and 11 of the experiment. Oocyst were obtained from the National Veterinary Reasearch Institute in Pulawy, Poland, thanks to the courtesy of Prof. Rzeżutka.

Fecal samples for parasitological texts were collected daily from each group, starting on the day of infection with C. parvum, and the birds' behavior was monitored, also for the presence of diarrhea. Fecal samples were stirred with a stirring rod, specimens of $7 \mathrm{~g}$ were sampled, and oocysts were isolated by the formol-ether concentration method. The resulting sediment was transferred to a slide and stained with carbol fuchsin and malachite green (Zehl-Neelsen) according to the method proposed by Henriksen and Pohlenz (9). DNA was isolated from the fecal samples using Qiagen Stool Mini Kit according to manufacturer's manual. Amplification of 18SSU rRNA Cryptosporidium gene was performed through nested-PCR according to Xiao procedure (32).

Every 3 days following the infection with C. parvum, 5 birds were randomly selected from each group. Blood samples for biochemical analyses were collected into tubes containing EDTA by rapid decapitation. The time between removing the birds from cages and blood sampling was approximately $20 \mathrm{sec}$. Blood samples were centrifuged at $2500 \times \mathrm{g}$ for $5 \mathrm{~min}$ and the serum was transferred into vials and stored at $-20^{\circ} \mathrm{C}$ until used. The determined serum biochemical parameters included enzyme activity: aspartate aminotransferase (AST) and alanine aminotransferase (ALT) - by the IFCC kinetic method, lactate dehydrogenase (LDH) - by the DGKC kinetic method, as well as total protein content (TP) - by the biuret test, albumin levels (ALB) - with the use of bromocresol green, and cholesterol levels (CHOL) - by the colorimetric method with cholesterol esterase and cholesterol oxidase. Measurements were performed with the use of the Cormay ${ }^{\circledR}$ ACCENT-200 chemistry analyzer and Cormay ${ }^{\circledR}$ reagents.

Birds were autopsied and the obtained intestinal tissue was subjected to microscopic examination. The samples were fixed in $10 \%$ neutralized formalin and embedded in paraffin blocks. Paraffin sections $(5 \mu \mathrm{m})$ were stained with haematoxylin and eosin (HE), PAS method according to McManus, and Ziehl-Neelsen method (Ziehl-Neelsen Cryptosporidium kit, Bio-Optica, Italy), which confirms the detection of parasites in tissue samples.

The degree of damage to the ileal mucosa was evaluated on a six-point scale, established by the authors: $0^{\circ}-$ absence of morphological lesions with coccidia present; $1^{\circ}$ - mild 
mucosal damage with insignificant shortening of the folds; $2^{\circ}$ - moderate mucosal damage with shortening of the folds; $3^{\circ}$-prominent shortening of the folds with lumen extension; $4^{\circ}$ - vestigial folds, atrophy of crypts; $5^{\circ}$ - total atrophy of the mucosa (crypts and folds) with parchment-like membrane.

The results were processed by two-way ANOVA - Duncan's test $(\mathrm{P} \leq 0.05)$.

The experiment was approved by the Local Ethics Committee (permission number: 69/2012).

\section{Results and discussion}

The quails in all groups remained asymptomatic during the entire experiment. In groups infected with Cryptosporidium parvum loosening of stool consistency was observed on days 3 and 6 p.i., but it could not be considered as diarrhea. Food and water intake remained unchanged the same as the behavior of the quails. Parasitological examination was negative.

Pathomorphological evaluation of intestinal tissue revealed mild changes in the alimentary tract in birds from groups $\mathrm{Cr}$ and $\mathrm{EM} / \mathrm{Cr}\left(\right.$ grade $1^{\circ}$ ), which were induced by different developmental stages of Cryptosporidium that were noted in the ileal lumen and mucosa. Low parasite counts did not have a damaging effect on the small intestinal lamina propria. Infiltrating lymphoid and myeloid cells, mucosal desquamation and mild congestion were observed in the small intestine.

Cholesterol in all groups of quails was on an even level and was continuously increasing with the age of the examined birds. In the control group $(\mathrm{C})$ and in both groups receiving $\mathrm{EM}(\mathrm{EM}$ and $\mathrm{EM} / \mathrm{Cr}) \mathrm{CHOL}$ concentration was significantly higher on the day 9 in comparison to day 0. Only in birds infected with Cryptosporidium parvum CHOL level on day 9 was lower than on the day 0 (Tab. 1).

Albumins. The albumin level was continuously increasing in birds from groups C and EM. In the $9^{\text {th }}$ day of the experiment it was statistically significantly higher than on day 0 . In infected birds from groups EM/Cr and $\mathrm{Cr}$ an increase of albumin level was initially observed and then a decline on day 9 . The highest levels of albumins were observed on the third day in the Cr group, and on day 9 in the EM group (Tab. 2). On the third day of the experiment a statistically significant difference in albumin level was observed between group $\mathrm{Cr}$ and group EM.

Total protein. TP level was continuously increasing in groups $\mathrm{C}$ and $\mathrm{EM} / \mathrm{Cr}$. In group $\mathrm{Cr}$ an increase in protein level was observed at days 3 and 6; on day 9 a substantial reduction was noted in comparison to the control group. Initially in the EM group the TP level decreased on day 3 and then on days 6 and 9 of the experiment it increased to a level significantly higher than in day 3 (Tab. 3).

ALT activity. In control group (C) activity of ALT increased on day 3 and then statistically significantly decreased on days 6 and 9. In C. parvum infected birds from groups $\mathrm{EM} / \mathrm{Cr}$ and $\mathrm{Cr}$ ALT activity decreased. On the third day of the study ALT activity in the ER/Cr group was significantly lower than in group $\mathrm{C}$. In the
Tab. 1. Cholesterol level depending on the date of the CHOL (mmol/l) examination

\begin{tabular}{|c|c|c|c|c|c|}
\hline \multirow{2}{*}{\multicolumn{2}{|c|}{ Group }} & \multicolumn{4}{|c|}{ Day of experiment } \\
\hline & & \multirow{2}{*}{$\begin{array}{c}0 \\
n=5\end{array}$} & \multirow{2}{*}{$\begin{array}{c}3 \\
n=5\end{array}$} & \multirow{2}{*}{$\begin{array}{c}\begin{array}{c}6 \\
n=5\end{array} \\
5.33 \\
\pm 0.55\end{array}$} & \multirow{2}{*}{$\begin{array}{c}9 \\
n=5\end{array}$} \\
\hline Control & $\begin{array}{c}\bar{x} \\
\text { sd }\end{array}$ & & & & \\
\hline $\mathrm{EM} / \mathrm{Cr}$ & $\begin{array}{c}\bar{x} \\
\text { sd }\end{array}$ & $\begin{array}{c}4.36 \\
\pm 0.95\end{array}$ & $\begin{array}{c}4.63 \\
\pm 1.63\end{array}$ & $\begin{array}{c}4.27 \\
\pm 1.94\end{array}$ & $\begin{array}{c}4.87 \\
\pm 1.19\end{array}$ \\
\hline $\mathrm{Cr}$ & $\begin{array}{c}\bar{X} \\
\text { sd }\end{array}$ & $\begin{array}{c}3.84 \\
\pm 1.20\end{array}$ & $\begin{array}{c}4.23 \\
\pm 1.15\end{array}$ & $\begin{array}{c}5.49 \\
\pm 2.55\end{array}$ & $\begin{array}{c}3.62 \\
\pm 0.20\end{array}$ \\
\hline EM & $\begin{array}{l}\bar{x} \\
\text { sd }\end{array}$ & $\begin{array}{c}4.36 \\
\pm 0.95\end{array}$ & $\begin{array}{c}5.87 \\
\pm 1.57\end{array}$ & $\begin{array}{c}5.46 \\
\pm 0.29\end{array}$ & $\begin{array}{r}5.02 \\
\pm 1.31\end{array}$ \\
\hline
\end{tabular}

Explanations (apply to all tables): $a, b-$ statistically significant differences $(\mathrm{p} \leq 0.05)$ between groups; $\mathrm{x}, \mathrm{y}, \mathrm{z}$ - statistically significant differences $(p \leq 0.05)$ within the group, depending of the time of examination

Tab. 2. Albumin level depending on the date of the ALB (g/l) examination

\begin{tabular}{|c|c|c|c|c|c|}
\hline \multirow{2}{*}{\multicolumn{2}{|c|}{ Group }} & \multicolumn{4}{|c|}{ Day of experiment } \\
\hline & & \multirow{2}{*}{$\begin{array}{c}0 \\
n=5 \\
9.93^{(x)} \\
\pm 2.38\end{array}$} & \multirow{2}{*}{$\begin{array}{c}3 \\
n=5\end{array}$} & \multirow{2}{*}{$\begin{array}{c}6 \\
\mathrm{n}=5 \\
12.95 \\
\pm 2.04\end{array}$} & \multirow{2}{*}{$\begin{array}{c}9 \\
n=5 \\
14.33^{(y)} \\
\pm 2.78\end{array}$} \\
\hline Control & $\begin{array}{c}\bar{x} \\
\text { sd }\end{array}$ & & & & \\
\hline $\mathrm{EM} / \mathrm{Cr}$ & $\begin{array}{c}\bar{x} \\
\text { sd }\end{array}$ & $\begin{array}{c}9.30 \\
\pm 2.61\end{array}$ & $\begin{array}{r}11.28 \\
\pm 3.09\end{array}$ & $\begin{array}{r}12.30 \\
\pm 3.42\end{array}$ & $\begin{array}{r}10.83 \\
\pm 2.50\end{array}$ \\
\hline $\mathrm{Cr}$ & $\begin{array}{c}\bar{X} \\
\text { sd }\end{array}$ & $\begin{array}{c}9.93 \\
\pm 2.38\end{array}$ & $\begin{array}{r}14.80^{\mathrm{a}} \\
\pm 3.08\end{array}$ & $\begin{array}{r}14.07 \\
\pm 2.33\end{array}$ & $\begin{array}{c}9.93 \\
\pm 6.01\end{array}$ \\
\hline EM & $\begin{array}{c}\bar{x} \\
\text { sd }\end{array}$ & $\begin{array}{l}9.30^{(x)} \\
\pm 2.61\end{array}$ & $\begin{array}{c}9.40^{b} \\
\pm 3.67\end{array}$ & $\begin{array}{r}13.45 \\
\pm 2.53\end{array}$ & $\begin{array}{c}15.23^{(y)} \\
\pm 2.77\end{array}$ \\
\hline
\end{tabular}

Tab. 3. Total protein count in particular groups of quails depending on date of the TP (g/l) examination

\begin{tabular}{|c|c|c|c|c|c|}
\hline \multirow{2}{*}{\multicolumn{2}{|c|}{ Group }} & \multicolumn{4}{|c|}{ Day of experiment } \\
\hline & & \multirow{2}{*}{$\begin{array}{c}0 \\
n=5\end{array}$} & \multirow{2}{*}{$\begin{array}{c}3 \\
n=5\end{array}$} & \multirow{2}{*}{$\begin{array}{c}6 \\
n=5\end{array}$} & \multirow{2}{*}{$\begin{array}{c}9 \\
n=5\end{array}$} \\
\hline Control & $\begin{array}{c}\bar{x} \\
\text { sd }\end{array}$ & & & & \\
\hline $\mathrm{EM} / \mathrm{Cr}$ & $\begin{array}{c}\bar{x} \\
\text { sd }\end{array}$ & $\begin{array}{r}31.65 \\
\pm 2.60\end{array}$ & $\begin{array}{r}32.83 \\
\pm 5.95\end{array}$ & $\begin{array}{r}34.45 \\
\pm 8.60\end{array}$ & $\begin{array}{r}34.43 \\
\pm 3.96\end{array}$ \\
\hline $\mathrm{Cr}$ & $\begin{array}{c}\bar{x} \\
\text { sd }\end{array}$ & $\begin{array}{l}30.55 \\
\pm 4.28\end{array}$ & $\begin{array}{l}37.60^{\mathrm{a}} \\
\pm 3.04\end{array}$ & $\begin{array}{l}37.93 \\
\pm 7.01\end{array}$ & $\begin{array}{l}28.30^{b} \\
\pm 9.64\end{array}$ \\
\hline EM & $\begin{array}{c}\bar{x} \\
\text { sd }\end{array}$ & $\begin{array}{l}31.65^{(x)} \\
\pm 2.60\end{array}$ & $\begin{array}{c}28.55^{b,(x)} \\
\pm 4.78\end{array}$ & $\begin{array}{c}39.20^{(x y)} \\
\pm 3.75\end{array}$ & $\begin{array}{c}39.85^{\mathrm{a},(z)} \\
\pm 2.53\end{array}$ \\
\hline
\end{tabular}

EM group ALT activity was continuously increasing, reaching values on day 6 and 9 significantly higher than in birds from the control group (Tab. 4).

AST activity. In the control group AST activity was continuously increasing; in $\mathrm{EM} / \mathrm{Cr}$ group it reached the highest value on day 6 . In group $\mathrm{Cr}$ it was lower in day 3 and 6 than in day 0 . In the EM group on day 6 it was at a similar level as on day 0 , but had an elevated value on day 3 and 9 (Tab. 5).

LDH activity. On day 0 in groups receiving EM (EM and $\mathrm{EM} / \mathrm{Cr}$ ) was significantly higher than in the control group. In groups $\mathrm{C}$ and $\mathrm{Cr}$ a statistically significant 
Tab. 4. ALT activity in particular groups of quails depending on date of the ALT (U/I) examination

\begin{tabular}{|c|c|c|c|c|c|}
\hline \multirow{2}{*}{\multicolumn{2}{|c|}{ Group }} & \multicolumn{4}{|c|}{ Day of experiment } \\
\hline & & \multirow{2}{*}{$\begin{array}{c}0 \\
n=5\end{array}$} & \multirow{2}{*}{$\begin{array}{c}3 \\
n=5 \\
13.00^{\mathrm{a}(y)} \\
\pm 1.83\end{array}$} & \multirow{2}{*}{$\begin{array}{c}6 \\
n=5\end{array}$} & \multirow{2}{*}{$\begin{array}{c}9 \\
n=5 \\
6.25^{\mathrm{a}(\mathrm{x})} \\
\pm 2.22\end{array}$} \\
\hline Control & $\begin{array}{c}\bar{x} \\
\text { sd }\end{array}$ & & & & \\
\hline $\mathrm{EM} / \mathrm{Cr}$ & $\begin{array}{c}\bar{x} \\
\text { sd }\end{array}$ & $\begin{array}{c}8.00 \\
\pm 2.83\end{array}$ & $\begin{array}{c}8.75^{\mathrm{b}} \\
\pm 2.22\end{array}$ & $\begin{array}{r}6.75 \\
\pm 0.5\end{array}$ & $\begin{array}{c}7.00 \\
\pm 2.16\end{array}$ \\
\hline $\mathrm{Cr}$ & $\begin{array}{l}\bar{x} \\
\text { sd }\end{array}$ & $\begin{array}{r}10.00 \\
\pm 3.37\end{array}$ & $\begin{array}{c}9.50 \\
\pm 2.38\end{array}$ & $\begin{array}{c}7.33 \\
\pm 1.15\end{array}$ & $\begin{array}{r}5.67^{\mathrm{a}} \\
\pm 2.89\end{array}$ \\
\hline EM & $\begin{array}{c}\bar{x} \\
\text { sd }\end{array}$ & $\begin{array}{c}8.00 \\
\pm 2.83\end{array}$ & $\begin{array}{r}9.75 \\
\pm 3.4\end{array}$ & $\begin{array}{l}9.25^{b} \\
\pm 2.5\end{array}$ & $\begin{array}{l}11.00^{b} \\
\pm 3.56\end{array}$ \\
\hline
\end{tabular}

Tab. 5. AST activity in particular groups of quails depending on date of the AST (U/I) examination

\begin{tabular}{|c|c|c|c|c|c|}
\hline \multirow{2}{*}{\multicolumn{2}{|c|}{ Group }} & \multicolumn{4}{|c|}{ Day of experiment } \\
\hline & & $0 n=5$ & $3 n=5$ & $6 n=5$ & $9 n=5$ \\
\hline C control & $\begin{array}{l}\bar{x} \\
\text { sd }\end{array}$ & $\begin{array}{r}121.75 \\
\pm 22.17\end{array}$ & $\begin{array}{r}126.75 \\
\pm 21.98\end{array}$ & $\begin{array}{c}139.75 \\
\pm 9.11\end{array}$ & $\begin{array}{r}140.50 \\
\pm 11.93\end{array}$ \\
\hline $\mathrm{EM} / \mathrm{Cr}$ & $\begin{array}{c}\bar{x} \\
\text { sd }\end{array}$ & $\begin{array}{r}116.25 \\
\pm 51.75\end{array}$ & $\begin{array}{r}121.75 \\
\pm 28.65\end{array}$ & $\begin{array}{r}156.25 \\
\pm 28.29\end{array}$ & $\begin{array}{r}128.50 \\
\pm 28.77\end{array}$ \\
\hline $\mathrm{Cr}$ & $\begin{array}{c}\bar{x} \\
\text { sd }\end{array}$ & $\begin{array}{r}121.75 \\
\pm 22.17\end{array}$ & $\begin{array}{r}100.25 \\
\pm 31.30\end{array}$ & $\begin{array}{r}124.67 \\
\pm 13.89\end{array}$ & $\begin{array}{r}106.00 \\
\pm 40.77\end{array}$ \\
\hline EM & $\begin{array}{c}\bar{x} \\
\text { sd }\end{array}$ & $\begin{array}{r}116.25 \\
\pm 51.75\end{array}$ & $\begin{array}{r}126.25 \\
\pm 34.49\end{array}$ & $\begin{array}{r}115.50 \\
\pm 42.37\end{array}$ & $\begin{array}{r}135.00 \\
\pm 29.54\end{array}$ \\
\hline
\end{tabular}

Tab. 6. LDH activity in particular groups of quails depending on date of the LDH (U/I) examination

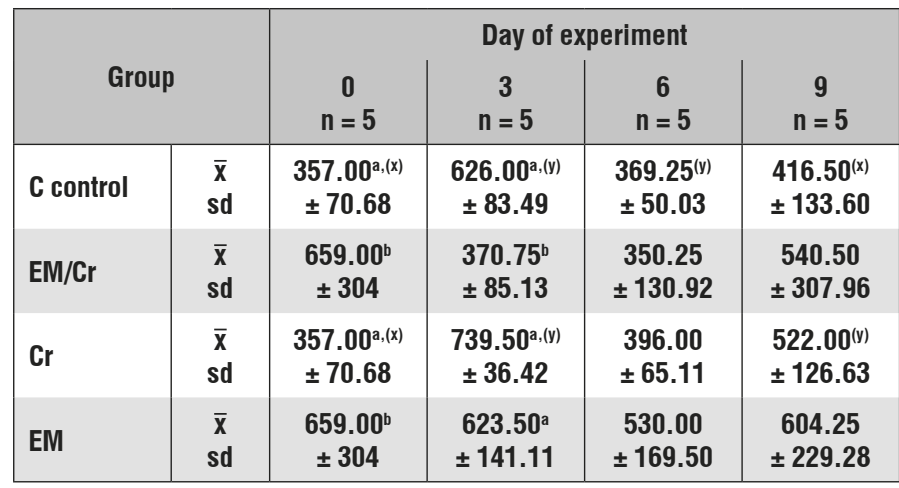

increase was noted on day 3 and then a decrease to the basic level from day 0 . In EM/Cr group on day 3 statistically significantly lower activity was observed in comparison to the control group (Tab. 6).

Various reports regarding the efficacy of EM in bird and animal breeding can be found in the literature. It is generally believed that EM improves feed conversion and body weight gains in various species of animals (2, $17,26)$ and stimulates immune responses to vaccine and environmental antigens $(3,8,10,30)$. EM supplementing influences the intestinal microbiota and thus may possibly reduce its susceptibility to protozoal infection. Various microorganisms might also influence biochemical parameters of the serum.

In our study neither EM supplementation nor Cryptospordium infection significantly influenced the cholesterol level. The available literature show various data. In a study by Sokół et al. (24) in laying hens receiving EM-supplemented water a significant increase of total cholesterol concentrations was observed compare to controls. Wondmeneh et al. (31) also analyzed total serum cholesterol level in broiler chicken during EM supplementation, but had opposite findings. They stated that EM supplementation in feed and water significantly decreased the level of total serum cholesterol in experimental animals. Also Safalaoh and Smith (21) demonstrated an insignificant decrease in serum cholesterol concentrations in broiler chickens administered EM for 42 days. Santoso et al. (22) and Salim et al. (19) analyzed effects of Bacillus subtilis addition and found significantly lower total cholesterol content in the Bacillus group compared to the control. Shareef and Al-Dabbagh (23) pointed to the significant lowest cholesterol level in broiler chickens in the $2.0 \%$ yeast addition group (Saccharomyces cerevisiae) compared to the control. Kalavathy et al. (11) have shown that diets with Lactobacillus addition reduces serum total cholesterol level and triglycerides level in experimental animals. In many cases a more visible hypocholesterolemic effect has been observed $(17,21,26)$, but its mechanism is not fully understood. It is hypothesized that some bacterial and yeast strains could incorporate cholesterol from the intestinal lumen into their cellular membrane reducing its absorbance into blood. As some of the strains are able to produce bile salt hydrolase, the enzyme responsible for bile salt deconjugation, they may also stimulate de novo synthesis of bile acids in the liver and thus reduce the cholesterol pool in the organism (11). Darabus et al. (7) observed significant reductions in the cholesterol level in broilers infected with Cryptosporidium, which they associated with the alteration of liver functioning and a reduction of bile production. In our study the insignificant decrease in the cholesterol level in birds from the $\mathrm{Cr}$ group may be associated with the inflammation process caused by Cryptosporidium since inflammatory mediators such as prostaglandins and leukotrienes are derivated from cholesterol.

The albumin level in our study increased in the EM and control groups (C), with a statistically significant increase visible between day 0 and day 9. Similarly, Sokó1 et al. (24) showed increased albumin levels (17.5\%) in laying hens after EM supplementation. Those two observation are the only data concerning increased level of albumin. Salim et al. (19) showed another observation. The authors revealed a constant level of albumin in broiler chickens after Bacillus subtilis addition.

The total protein level in our study at the last day of the experiment was significantly lower in the $\mathrm{Cr}$ group compared to the control and EM groups. Observations of other authors after probiotic and prebiotic applications are convergent. A similar increased total protein level was demonstrated by Salim et al. (19) after Bacillus subtilis supplementation. Shareef and Al-Dabbagh (23) indicated a significantly increased level of total serum protein in treatments groups $(1,1.5,2.0 \%$ addition of the yeasts) compared to other treatments. 
The ALT activity was significantly different on day 6 between the EM group and control, as well as at the $9^{\text {th }}$ day between EM and control and Cr groups. In both cases, the EM group showed higher ALT activity. The earlier study of Sokół et al. (24) in laying hens with EM addition showed a decrease of ALT activity (14.4\%). An unchanged level of ALT activity was observed after yeasts and Bacillus subtilis addition $(23,19)$. In our study, in the Cr group the activity of ALT continuously decreased while the study of Darabus et al. (7) shows an increase of ALT activity in Cryptosporidium infected broiler chickens. Thus, our observation differs from earlier findings.

Our study did find not significant differences in the AST activity. A similar observation with no effect to yeast addition was made by Shareef and Al-Dabbagh (23). Moreover, Bacillus subtilis addition did not reveal AST activity (19).

The observation of LDH activity showed an increasing level in the Cr group and a decreasing level in EM and EM/Cr groups. The earlier study of Sokół et al. (24) showed other data. The authors indicated increased LDH activity (12.1\%) in laying hens in the EM group. No further data concerning the LDH level during probiotic and prebiotic administration are available. In the present study, the observed decrease in LDH activity in birds that had been administered EM could be attributed to the influence of the microorganisms contained in the preparations, in particular Lactobacillus buchneri involved an anaerobic conversion of lactic acid (14).

The results of these studies suggest that infecting quails with Cryptosporidium parvum was only partially successful, as the coproscopic examination was negative, but in the histopathological examination different stages of the parasite were detected in the illeal tissue. This suggests that the parasite was probably unable to develop oocysts which could survive intestinal passage. The addition of EM does not increase the metabolic rate in animals and has no significant effect on biochemical parameters. Further research into the use of EM supplements in animals and birds is required with the involvement of larger populations of animals, in particular animals with a longer lifespan.

\section{References}

1. Alexopulos C., Georgoulakis I. E., Tzivara A., Kritas S. K., Siochu A., Kyriakis $S$. $C$.: Field evaluation of the efficacy of a probiotic containing Bacillus lichenioformis and Bacillus subtilis spores, on the health status and performance of sows and their litter. J. Anim. Physiol. Anim. Nutr. (Berl.) 2004, 88, 381-392.

2. Anjum A. D., Hussain T., Rizvi F., Gilani G., Javaid T.: Influence 6 of Effective Microorganisms on Health and Immune System of Broilers under Experimental Conditions. $5^{\text {th }}$ Conf. on the Technology of Effective Microorganisms at Sara Buri, Thailand, 10-11 Dec. 1996, APNAN ans INFRC., p. 5.

3. Anjum M. I., Khan A. G., Azim A., Afzal M.: Effect of dietary supplementation of multi-strain probiotic on broiler growth performance. Pakistan Vet. J. 2005 $25,25-29$

4. Baranowski A.: Preparat „Efektywne Mikroorganizmy” $\left(\mathrm{EM}^{\circledR}\right)$ - próby zastosowania w rolnictwie. Przegląd Hodowlany 2004, 72, 26-27.

5. Chantsawang S., Watcharangkul P.: Influence of effective microorganisms on the quality of poultry product. Proc. Internat. Conf. in Kyusei, Nature Farming. Sara Buri, Thailand 1997, p. 133-150.

6. Daly M. J., Steward D. P. C.: Influence of „Effective Microorganisms” (EM) on vegetative production and carbon mineralization - a preliminary investigation. J. Sust. Agric. 1999, 14, 15-25.
7. Darabus G. H., Mederle O., Mederle N., Olariu T. R., Oprescu I., Marariu S., Imre K., Ilie M., Hotea I.: The study of some biochemical parameters in cryptosporidium experimental infection in broiler chickens. Lucr. Stiinti. Med. Vet. 2008, 61, 344-347.

8. Haghighi H. R., Gong C. K., Gyles M. A., Hayes M. A., Zhou H.: Probiotics stimulate production of natural antibodies in chickens. Clin. Vaccine Immunol. 2006, 13, 975-980.

9. Henriksen S. A., Pohlenz J. E.: Staining of Cryptosporidia by a modified ZiehlNeelsen technique. Acta Vet. Scand. 1981, 22, 594-596.

10. Kabir S. M., Rahman M. M., Rahman M. B., Ahmed S. U.: The dynamics of probiotics on growth performance and immune responses in brojler chickens. Poult. Sci. 2004, 3, 361-364.

11. Kalavathy R., Abdullah N., Jalaludin S., Ho Y. W.: Effects of Lactobacillus cultures on growth performance, abdominal fat deposition, serum lipids and weight of organs of broiler chickens. Brit. Poultry Sci. 2003, 44, 139-144.

12. Ke B., Liang Y. F., Hong Z. H., Higa T., Aruoma O. I.: Evaluation of the toxicity and safety of the antioxidant beverage effective microorganisma X (EM_X) in animals models. Environ. Toxicol. Pharmacol. 2005, 20, 313-330.

13. Khaliq A., Abdasi M. K., Hussaiun T.: Effects of integrated use of organic and inorganic nutrient sources with effective microorganisms (EM) on seed cotton field in Pakistan. Biores. Toechnol. 2006, 97, 967-972.

14. Lindsay D. S., Blagburn B. L., Ernest J. A.: Experimental Cryptosporidium parvum infection in chickens. J. Parasitol. 1987, 73, 242-244.

15. Oude Elferink S. J., Krooneman J., Gottschal J. C., Spoelstra S. F., Faber F, Driehuis F: Anaerobic conversion of lactis acid and 1,2-propanediol by Lactobacillus buchneri. Appl. Environ. Microbiol. 2001, 67, 125-132.

16. Pavlasek I.: Findings of Cryptosporidia in the stomach of chickens and of exotic and wild birds. Veterinarstvi 2001, 51, 103-108.

17. Ryan U.: Cryptosporidium in birds, fish and amphibians. Exp. Parsitol. 2010, 124, 113-120.

18. Ryan U., Paparinia A., Monisb P., Hijjawic N.: It's official - Cryptosporidium is a gregarine: What are the implications for the water industry? Water Res. 2016 105, 305-313.

19. Salim H. A., Abd-Allah O. A., Fararh K. M.: Effect of feeding probiotic on hematological, biochemical properties and immune response in broiler. Benha Vet. Med. J. 2011, 22, 35-43.

20. Safalaoh A. C. L.: Body weight gain, dressing, percentage, abdominal fat and serum cholesterol of broilers supplemented with a microbial preparation. AJFAND 2006, 6, 1-10

21. Safalaoh A. C. L., Smith G. A.: Effective microorganisms (EM) as an alternative to antibiotics in broiler diets: effect on broiler growth performance, feed utilization and serum cholesterol. Proc. $6^{\text {th }}$ Kyusei Nature Forming Proceeding, Pretoria, South Africa 2001, p. 150-155.

22. Santoso U., Tanaka K., Ohtani S.: Effect of dried Bacillus subtilis culture on growth, body composition and hepatic lipogenic enzyme activity in female broiler chicks. Brit. J. Nutr. 1995, 74, 523-529.

23. Shareef A. M., Al-Dabbagh A. S. A.: Effect of probiotic (Saccharomyces cerevisiae) on performance of broiler chicks. Iraqi J. Vet. Sci. 2009, 23, 23-29.

24. Sokót R., Michalczyk M., Spodniewska A., Barski D.: The influence of administering „effective microorganisms" to pullets on chosen haematological and biochemical blond indexes. Pol. J. Vet. Sci. 2009, 12, 519-522.

25. Sreter T., Varga I.: Cryptosporidiosis in birds - A review. Vet. Parasitol. 2008 , 7, 261-279

26. Szeleszczuk P.: Weterynaryjne aspekty stosowania żywych kultur mikroorganizmów w praktyce drobiarskiej. Magazyn Wet. 2005a, 14, 51-52.

27. Szeleszczuk P.: Weterynaryjne aspekty stosowania żywych kultur mikroorganizmów w praktyce drobiarskiej Magazyn Wet. 2005b, 14, 56-58.

28. Wang Y., Cho J. H., Chen Y. J., Yoo J. S., Huang Y., Kim H. J., Kim I. H.: The effect of probiotic BioPlus $2 \mathrm{~B}^{\circledR}$ on growth performance, dry matter and nitrogen digestibility and lurry noxious gas emission in growing pigs. Livest. Sci. 2009, $120,35-42$

29. Wondmeneh E., Getachew T., Dessie T.: Effect of Effective Microorganisms $\left(\mathrm{EM}^{\circledR}\right)$ on the Growth Parameters of Fayoumi and Horro Chicken. Int. J. Poult Sci. 2011, 10, 185-188.

30. Wondmeneh E., Getachew T., Dessie T.: Immunomodulatory Effect of Effective Microorganisms $\left(\mathrm{EM}^{\circledR}\right)$ in Chickens. Res. J. Immunol. 2012, 5, 17-23.

31. Wondmeneh E., Melesse A., Dessie T.: Effect of Effective Microorganisms ${ }^{\circledR}$ on Growth Parameters and Serum Cholesterol Levels in Broilers. Afr. J. Agri. Res. 2011b, 6 (16) 3841-3846.

32. Xiao L., Escalante L., Yang C., Sulaiman I., Escalante A. A., Montali R. J., Fayer R., Lal A. A.: Phylogenetic analysis of Cryptosporidium parasites based on the small-subunit rRNA gene locus. Appl. Environ. Microbiol. 1999, 65, $1578-1583$

Correspodning author: Dr hab. Rajmund Sokól, Prof. UWM, Department of Parasitology and Invasive Diseases, Oczapowskiego 13, 10-719 Olsztyn, Poland; e-mail: rajmund.sokol@uwm.edu.pl 